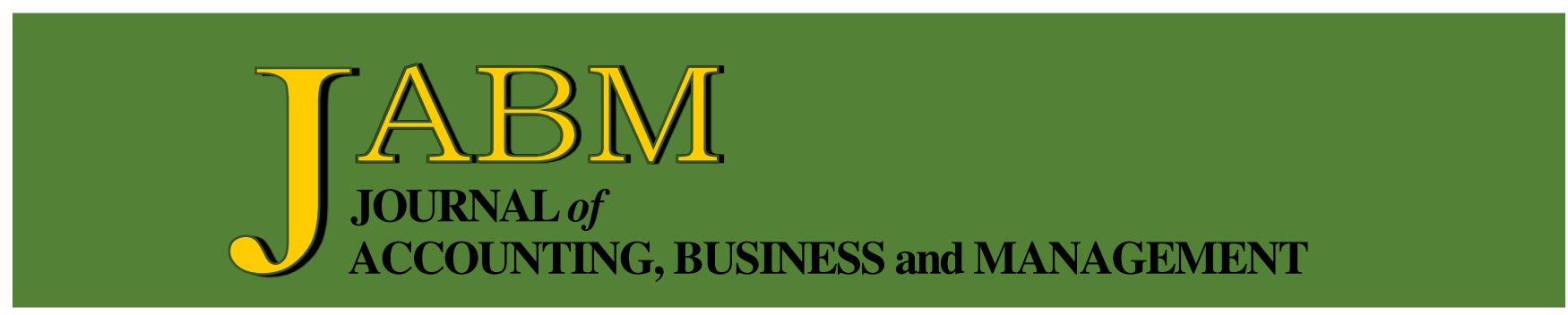

Life Insurance Companies: Determinants of Cost Efficiency and Profitability

Joseph Kwadwo Tuffour, Kenneth Ofori-Boateng, Williams Ohemeng, and Jane Kabukuor Akuaku

Subprime Crisis - A Corporate Acquisition Opportunity?

Vishal Srivastava, Sunder Ram Korivi, and Dipasha Sharma

Consequences of Weak Internal Controls Over Financial Reporting: Foreign versus U.S. Firms

Kathleen Bakarich and Devon Baranek

Impact of Organizational Commitment on Accounting Professionals' Performance: Case of Accounting Firms

Lassaad Abdelmoula and Sami Boudabbous

The Objectives of Sharia Management Accounting Information Reporting: Identification of Values and Characteristics

Sonhaji, Abdul Kadir Usri, and Hedher Tuakia

The Impact of Customer's Perception of the Practices of Corporate Social Responsibility on Purchase Intention

Doaa Abd El Samea and Ahmed Rashed

Corporate Financial Distress: The Impact of Profitability, Liquidity, Asset Productivity, Activity and Solvency

Karikari Amoa-Gyarteng

Determinant Factors of Social Cohesion and Inclusion of Street Vendors in Jakarta: Key Factor Surviving During Covid-19 Pandemic

Beti Nurbaiti 


\title{
Impact of Organizational Commitment on Accounting Professionals' Performance: Case of Accounting Firms
}

\author{
Lassaad Abdelmoula* \\ Sami Boudabbous ${ }^{\dagger}$
}

\begin{abstract}
Purpose-This study aimed to examine the impact of organizational commitment (OC) on job performance.

Design/methodology/approach - Our methodology was applied to 240 accounting professionals who work in accounting firms in Tunisia.

Findings - The results show that both affective and continuance dimensions have a positive and significant impact on performance, whereas the normative commitment has a negative but non-significant effect.

Originality/value - To our knowledge, very little research has been conducted on the accounting profession. Our study aimed to fill this gap by studying the impact of OC on job performance of accounting professionals working in Tunisian accounting firms.
\end{abstract}

Keywords: organizational commitment, affective commitment, normative commitment, continuance commitment, job performance.

\section{INTRODUCTION}

\subsection{Background and Objective of this Study}

The impact of organizational commitment (OC) on job performance remains a controversial topic in earlier literature (Raza et al., 2015). Indeed, several research studies have addressed this issue, but the results are mixed. The majority of these studies have investigated the case of teachers (Kamis et al., 2013), doctors and nurses (Berberoglu \& Secim, 2015), and employees in general (Metin \& Asli, 2018). However, to our knowledge, very little research has been carried out within the framework of the accounting profession and, thus, results from previous studies cannot be applied to this sector. In this context, our study aimed to fill this gap by studying the impact of OC on job performance of accounting professionals working in Tunisian accounting firms.

This paper will be organized as follows: First, we propose the literature review that led us to pose the hypotheses to be tested. We will then present the methodology of the research. Subsequently, the results will be discussed. Finally, the paper ends with a conclusion.

\section{LITERATURE REVIEW}

\subsection{The Relationship between Organizational Commitment and Job Performance}

The relationship between organizational commitment and employee performance is based on the leader-member exchange (LMX) theory. The studies of

\footnotetext{
* Corresponding author. Department of Accounting, Faculty of Economics and Management of Sfax, Tunisia. E-mail: lassaad.abd86@gmail.com.

t Department of Accounting, Faculty of Economics and Management of Sfax, Tunisia. E-mail: samiboudabbous2002@yahoo.fr.
} 
Liden et al. (2000) and Wayne et al. (2002) found that high-quality LMX leads employees to develop OC and improve job performance. Shaw et al. (2003) studied OC and performance, using a sample of 226 employees and subordinates of banks in the United Arab Emirates. They showed that there is a positive relationship between OC and employee job performance.

In the same vein, Irefin and Mechanic (2014) examined the effect of employee commitment on organizational performance with a particular interest in Coca Cola in Nigeria using a sample of 120 employees (managers and supervisors). They showed that there is a strong relationship between employees' $\mathrm{OC}$ and performance.

Kamis et al. (2013) studied the impact of OC and individual competencies on teacher performance based on a sample of 118 elementary school teachers. They showed that organizational commitment has a direct, significant, and positive influence on their performance.

In the same context, Mansour et al. (2013) affirmed that organizational commitment is positively correlated with performance perceived as a result of their study of human resources management (HRM) practices and business performance in the Tunisian financial services sector.

In addition, Berberoglu and Secim (2015) studied the impact of OC on job performance in the health sector in hospitals in Northern Cyprus on a sample of managers, doctors, nurses, and chemists. They found a positive and significant relationship between $\mathrm{OC}$ and performance.

Furthermore, Ghorbanpour et al. (2014) studied the effect of OC on accountants' performance in the community of chartered accountants of Tehran using a sample of 640 members. They stated that there is a positive and significant relationship between OC and the job performance of auditors.

Similarly, Krishnanathan and Mangaleswaran (2018) examined OC and employee performance with special reference to administrative officers at the University of Jaffna, Sri Lanka (40 administrative officers). They found that OC has a significant impact on employee performance, suggesting that employees' organizational commitment can improve their job performance.

Similarly, Suharto et al. (2019) studied the impact of OC on job performance on a sample of 350 employees. They showed that OC directly influences job performance.

From the above, we hypothesize that:

Hypothesis $1\left(\mathbf{H}_{\mathbf{1}}\right)$ : organizational commitment has a positive and significant effect on the job performance of accounting professionals.

\subsubsection{The relationship between affective, continuance, and normative commitment and job performance}

Meyer and Allen (1991) found that affective commitment is positively correlated with job performance, while normative and continuance commitments are negatively correlated. However, Meyer et al. (1993) found that only affective and normative commitments are positively correlated with job performance, while the continuance commitment has a negative impact.

Besides, Folorunso et al. (2014) conducted a study on the impact of the OC dimensions on the performance of Oyo academic staff using a sample of 197 respondents from two institutions of higher education. They found that there is a significant and positive relationship between the dimensions of $\mathrm{OC}$ and job performance.

For their part, Rafiei et al. (2014) studied the effect of the three dimensions of organizational commitment on employee performance. Their sample was composed of 
244 employees. They showed that OC has a positive and significant effect on performance and that the three dimensions of organizational commitment have a positive and significant effect on job performance.

In this context, Dixit and Bhati (2012) examined employees' OC and its impact on productivity in the Indian automotive components industry using a sample of 50 managers. They found that employee commitments (affective, normative, and continuance) are significantly associated with sustained productivity.

Memari et al. (2013) studied the impact of OC on employee performance with Malik Bank staff through 230 questionnaires distributed to the bank's administrative staff in Sanandaj. The results revealed that the three dimensions of OC have a positive and significant effect on employee performance in Iran.

In another study, Metin and Asli (2018) examined the relationship between OC and work performance in Industrial Enterprises on a sample of 329 employees working in businesses operating in Konya Chamber of Commerce and Industry in Turkey. They found that affective commitment has a significant and positive impact on work performance. However, normative and continuance commitments have no significant effect on work performance.

Al Zeifiti and Mohamad (2017) studied the influence of organizational commitment on Omani public employees' work performance based on a sample of 335 middle-level managers of Omani public civil service organizations. They found a positive relationship between the affective commitment of senior executives and the performance of the organization, but a negative relationship between the normative and continuance commitment of executives and the financial performance of the organization.

In this regard, we present the following sub-hypotheses:

Hypothesis 1-1 $\left(\mathbf{H}_{1-1}\right)$ : affective commitment has a positive and significant effect on the performance of accounting professionals.

Hypothesis 1-2 ( $\left.\mathbf{H}_{1-2}\right)$ : normative commitment has a positive and significant effect on the performance of accounting professionals.

Hypothesis 1-3 ( $\left.\mathbf{H}_{1-3}\right)$ : continuance commitment has a positive and significant effect on the performance of accounting professionals.

Figure 1

Our research model is detailed in Figure 1.

Research Model

Organizational Commitment:

- Affective Commitment

- Normative Commitment

- Continuance Commitment

\section{RESEARCH METHODOLOGY}

\subsection{Method of Data Collection}

This research was entirely based on the answers received from 240 accounting professionals who work in accounting offices in Tunisia. In fact, out of 250 respondents, 240 accounting professionals were selected.

\subsection{Measurement of Variables}

Table 1 illustrates the different variables of our model. The first variable dealing with job performance (variable to be explained) was measured by 12 items according to Choo (1986) and Fisher (2001). 
The second variable, which was based on OC (explanatory variable), was measured by 18 items developed by (Meyer \& Allen, 1997) 6 for affective commitment, 6 for continuance commitment, and 6 for normative commitment).

Finally, the control variables, measured according to a disjunctive table, are three-fold, namely, age, seniority and position at the firm level.

Table 1

Variables' Measurement

\begin{tabular}{lcl}
\hline \multicolumn{1}{c}{ Variables } & Measures & \multicolumn{1}{c}{ Authors } \\
\hline Job Performance & 12 items & Choo (1986) and Fisher (2001) \\
Organizational Commitment & 18 items & Meyer and Allen (1997) \\
\hline
\end{tabular}

\subsection{Data Analysis Methods}

Before formulating and collecting the questionnaire data, via the statistical package for the social sciences (SPSS) software, the entirety of the relevant variables was encoded in a structurally constructed database to facilitate the necessary calculations.

The purpose of this section is to depict the descriptive analyses and homogeneity tests of the constructs. In the first stage, a cross-tabulation of socio-demographic characteristics was prepared. Then, we proceeded with the dimensionality, reparation, and reliability of the concepts.

These concepts would allow us to aggregate and, when necessary, purify the items making up the different items of the questionnaire, through the factor analysis and Cronbach alpha test.

Before initiating the first level of the analysis, necessary for validating the advanced hypotheses, a few remarks should be highlighted. For factor analysis, if the initial (orthogonal) principal component analysis (PCA) does not display a clear factor structure, due to items displaying contributions exceeding 0.30 with respect to several factors (as is the case with a wide range of scales), it is desirable to introduce an oblique rotation to adjust the proposed structure. Indeed, this rotation helps us to interpret the factor's purposes through increasing the correlation coefficients' value of certain items with the new representation axes (Bagozzi et al., 1991; Evrard et al., 1997).

Then, we outline the methodology applied to test the research hypotheses and highlight the results obtained. Our goal consists in emphasizing the role of the three OC dimensions in maintaining job performance. Indeed, the implemented approach involves two steps.

In the first step, we proceed with the validation of our hypotheses $\left(\mathrm{H}_{1-1}\right.$ and $\mathrm{H}_{1-2}$ ), i.e., the effect of both the affective and normative commitments on job performance, along with the improvement brought about by the introduction of the continuance commitment dimension $\left(\mathrm{H}_{1-3}\right)$.

At this level, hierarchical regression analyses were implemented. The second step is an attempt to control for the respective effects of "age, seniority and position" on the results achieved (Schawartz, 1978).

\section{RESULTS AND DISCUSSION}

This section is devoted to discussing the results of the impact of $\mathrm{OC}$ on job performance. 


\subsection{The Principal Component Analysis (PCA)}

\subsubsection{Organizational commitment}

Table 2

The Organizational Commitment Factorial Analysis

\begin{tabular}{|c|c|c|c|}
\hline $\begin{array}{l}\text { Organizational Commitment } \\
\text { Items }\end{array}$ & $\begin{array}{c}\text { Axis } \mathrm{F}_{1} \\
\text { Continuance } \\
\text { Commitment } \\
\end{array}$ & $\begin{array}{c}\text { Axis } \mathrm{F}_{2} \\
\text { Normative } \\
\text { Commitment }\end{array}$ & $\begin{array}{c}\text { Axis } \mathrm{F}_{3} \\
\text { Affective } \\
\text { Commitment }\end{array}$ \\
\hline $\begin{array}{l}\text { I really have a feeling of belonging to } \\
\text { my firm. }\end{array}$ & 0.039 & 0.122 & 0.663 \\
\hline My firm means a lot to me. & 0.105 & 0.092 & 0.712 \\
\hline I am proud to belong to this firm. & 0.148 & 0.111 & 0.604 \\
\hline I feel emotionally attached to my firm. & 0.123 & 0.064 & 0.577 \\
\hline $\begin{array}{l}\text { I really feel like "being part of the } \\
\text { family" in my firm. }\end{array}$ & 0.127 & 0.025 & 0.693 \\
\hline $\begin{array}{l}\text { I consider the problems of my firm as } \\
\text { mine. }\end{array}$ & 0.02 & 0.157 & 0.801 \\
\hline $\begin{array}{l}\text { It would not be morally correct to } \\
\text { leave my firm now. }\end{array}$ & 0.28 & 0.897 & 0.045 \\
\hline $\begin{array}{l}\text { It would not be correct to leave my } \\
\text { firm now even if I found an } \\
\text { advantage. }\end{array}$ & 0.292 & 0.885 & 0.205 \\
\hline $\begin{array}{l}\text { I feel that I would be guilty if I left my } \\
\text { firm now. }\end{array}$ & 0.267 & 0.912 & 0.226 \\
\hline $\begin{array}{l}\text { I would betray the trust that I am } \\
\text { granted if I left my firm now. }\end{array}$ & 0.177 & 0.852 & 0.265 \\
\hline $\begin{array}{l}\text { If I were offered a position in another } \\
\text { firm, I would not find it correct to } \\
\text { leave my current firm. }\end{array}$ & 0.0074 & 0.771 & 0.053 \\
\hline $\begin{array}{l}\text { I am not leaving my firm now because } \\
\text { I feel that I have obligations towards } \\
\text { some people who work there. }\end{array}$ & 0.001 & 0.639 & 0.054 \\
\hline $\begin{array}{l}\text { I have no choice but to stay in my } \\
\text { current firm. }\end{array}$ & 0.928 & 0.191 & 0.112 \\
\hline $\begin{array}{l}\text { I stay in my current firm because I do } \\
\text { not see if I could go elsewhere. }\end{array}$ & 0.908 & 0.194 & 0.208 \\
\hline $\begin{array}{l}\text { I continue to work for my current firm } \\
\text { because I feel that my opportunities to } \\
\text { work elsewhere are too limited. }\end{array}$ & 0.828 & 0.206 & 0.257 \\
\hline $\begin{array}{l}\text { I continue to work for my current firm } \\
\text { because I derive many benefits from it. }\end{array}$ & 0.668 & 0.291 & 0.253 \\
\hline $\begin{array}{l}\text { I continue to work for my current firm } \\
\text { because I see a lot more advantages } \\
\text { than disadvantages. }\end{array}$ & 0.75 & 0.251 & 0.154 \\
\hline $\begin{array}{l}\text { I continue to work for this firm } \\
\text { because another firm would not offer } \\
\text { me the same benefits. }\end{array}$ & 0.693 & 0.197 & 0.126 \\
\hline Eigenvalue & 2.047 & 1.991 & 1.878 \\
\hline$\%$ Variance explained & 28.97 & 25.106 & 24.714 \\
\hline $\begin{array}{l}\text { \% Total Variance } \\
\text { Cronbach's Alpha }\end{array}$ & & $\begin{array}{c}78.79 \\
0.714012\end{array}$ & \\
\hline
\end{tabular}


In what follows, we will discuss the results of the PCA of OC and job performance. Indeed, the relationship with the organization is depicted through three dimensions of commitment. The first mode is continuance commitment, as depicted through the items: I have no choice but to stay in my current organization (continuance commitment 1); I stay in my current organization because I do not see if I could go elsewhere (continuance commitment 2); I continue to work for my current organization because I feel that my opportunities to work elsewhere are too limited (continuance commitment 3); I continue to work for my current organization because I derive many benefits from it (continuance commitment 4); I continue to work for my current organization because I see a lot more advantages than disadvantages (continuance commitment 5); and I continue to work for this organization because another organization would not offer me the same benefits (continuance commitment 6). Normative, involving items such as: it would not be morally correct to leave my organization now (normative commitment 1); It would not be correct to leave my organization now even if I found an advantage. (normative commitment 2), I feel that I would be guilty if I left my organization now (normative commitment 3); I do not leave my organization even if I find another advantage (normative commitment 4); If I were offered a position in another organization, I would not find it correct to leave my current organization (normative commitment 5); I am not leaving my organization now because I feel that I have obligations towards some people who work there (normative commitment 6). As for the third mode, it refers to affective commitment involving items such as: I really have a feeling of belonging to my organization.(affective commitment 1); My organization means a lot to me (affective commitment 2); I am proud to belong to this organization (affective commitment 3); I feel emotionally attached to my company (affective commitment 4); I really feel like "being part of the family" in my company (affective commitment 5) and I consider the problems of my company as mine (affective commitment 6).

Thus, our constructed scale should help in achieving a multi-dimensional factorial structure. In fact, an initial review of the PCA reveals the prevalence of three factor axes (see Appendix). For an effective interpretation of these factors, an oblique rotation seems necessary.

The applied rotation provides a clear depiction of the links between the three aspects of commitment and their respective components, as the factor contributions display higher values.

All items contribute significantly (contribution greater than 0.483 ) and integrally (no contribution is greater than or equal to 0.30 on another factor) to the dimension they constitute. Moreover, the three axes prove to restore a total variance of $78.79 \%$.

To confirm the homogeneity of each of these dimensions, a Cronbach alpha test was administered. Concerning the first factorial axis, Table 2 highlights that the reliability coefficient $\alpha$ is slightly higher than the set threshold (0.714). It is all the more acceptable that this scale is exploratory.

\subsubsection{Job performance}

Prior to regrouping the 12 items, an internal consistency test was administered. It is worth noting that the Cronbach's alpha is acceptable (0.621). Noteworthy, however, and as indicated in Table 3, is that the elimination of the "maintain the amount of work" item helps improve the Cronbach's alpha by 0.1 point (0.723). As for job performance, it is reflected through two aspects. The first is based on task performance as depicted through the items: Maintaining quality at work; communicating orally and in writing; accepting responsibility and taking action; exercising professional skills and 
care and adapting to new or different job situations. The second aspect is contextual involving items such as following policies and procedures; planning and organizing work; getting along with others within the firm; dealing with clients outside the firm and supervising others. In this way, the constructed scale should lead to a twodimensional factor structure. An examination of the initial PCA within the sample reflects two major factors.

Still, the components' matrix remains unclear. Indeed, both items "following the organization's policies and procedures" and "accepting responsibility and taking action" display factorial contributions exceeding 0.30 with regard to both dimensions. For a clear interpretation of these factors, an oblique rotation is imposed.

The undertaken rotation highlights the links between the two facets of job performance and their respective components, as factor contributions exhibit higher values (see Table 3). All items contribute significantly (by more than 0.7 ) and integrally (no contribution is greater than or equal to 0.30 on another factor) to the dimension they make up. Moreover, the first factor provides $40.78 \%$ of the collected information. For the second factor, which accounts for $23.6 \%$ of the total variance and the total of their respective variances is equal to $64.38 \%$. Hence, the scale representing the model's variable to be explained is homogeneous. Table 3 highlights that the reliability coefficient $\alpha$ is slightly higher than the set threshold (0.723). It is all the more acceptable that this scale is exploratory.

Table 3

PCA. Job Performance (Following Oblique Rotation)

\begin{tabular}{lcc}
\hline \multicolumn{1}{c}{ Items } & $\begin{array}{c}\text { Axis F1 } \\
\text { Task } \\
\text { Performance }\end{array}$ & $\begin{array}{c}\text { Axis F2 } \\
\text { Contextual } \\
\text { Performance }\end{array}$ \\
\hline Maintaining Quality of Work & $\mathbf{0 . 7 9 5}$ & 0.109 \\
Communicating Orally & $\mathbf{0 . 8 2 9}$ & 0.079 \\
Communicating in Writing & $\mathbf{0 . 8 3 4}$ & 0.116 \\
Accepting Responsibility and Initiating Action & $\mathbf{0 . 8 2 1}$ & 0.176 \\
Exercising Professional Skills and Care & $\mathbf{0 . 7 4 1}$ & 0.097 \\
Adapting to New or Different Job Situations & $\mathbf{0 . 7 3 5}$ & 0.259 \\
Following Policies and Procedures & 0.296 & $\mathbf{0 . 7 6 3}$ \\
Planning and Organizing Work & 0.294 & $\mathbf{0 . 7 0 1}$ \\
Getting Along with Others Within the Firm & 0.268 & $\mathbf{0 . 7 3 5}$ \\
Dealing with Clients Outside the Firm & 0.085 & $\mathbf{0 . 8 3 5}$ \\
Supervising Others & 0.155 & $\mathbf{0 . 8 3 6}$ \\
Eigenalue & 6.032 & 1.05 \\
\% Variance Explained & 40.78 & 23.6 \\
\hline \multicolumn{2}{c}{ \%otal Variance } & $\mathbf{6 4 . 3 8}$ \\
\multicolumn{2}{c}{ Cronbach's Alpha } & $\mathbf{0 . 7 2 3 1 0 4}$ \\
\hline
\end{tabular}

\subsection{Hierarchical Regression}

For regression analyses, the scores were calculated for the variables introduced by adding the items corresponding to each. Their averages and standard deviations are presented in Table 4. The examination of compliance with the regression conditions was carried out before the analyses.

Insert Table 4 here.

To investigate the extent to which the expanded model we proposed reflects job performance, the two dimensions of OC "affective commitment" and "normative commitment" were included in a first stage. Then, the continuance commitment was 
added in a second stage. Finally, the three variables "age", "seniority" and "position" were introduced.

Table 4

Compliance with the Regression Application Conditions

\begin{tabular}{lccccc}
\hline \multicolumn{1}{c}{ Dimensions } & $\begin{array}{c}\text { Number } \\
\text { of Items }\end{array}$ & $\begin{array}{c}\text { Scope/ } \\
\text { Item }\end{array}$ & $\begin{array}{c}\text { Extent } \\
\text { of scale }\end{array}$ & Average & $\begin{array}{c}\text { Standard } \\
\text { Deviation }\end{array}$ \\
\hline Task Performance & 6 & $1-5$ & $6-30$ & 10.049 & 0.1149 \\
Contextual Performance & 5 & $1-5$ & $5-25$ & 18.596 & 0.1947 \\
Affective Commitment & 6 & $1-5$ & $6-30$ & 14.119 & 0.3007 \\
Normative Commitment & 6 & $1-5$ & $6-30$ & 8.822 & 0.1231 \\
Continuance Commitment & 6 & $1-5$ & $6-30$ & 16.09 & 0.3521 \\
Age & 1 & $1-4$ & $1-4$ & 1.546 & 0.062 \\
Seniority & 1 & $1-3$ & $1-3$ & 1.747 & 0.048 \\
Position & 1 & $1-4$ & $1-4$ & 1.579 & 0.053 \\
\hline
\end{tabular}

The results are detailed in Table 6,7 and 8 below presenting the marginal contribution to the prediction of the job performance of each complementary variable with respect to the step.

Table 5

Hierarchical Regression for Task and Contextual Performances

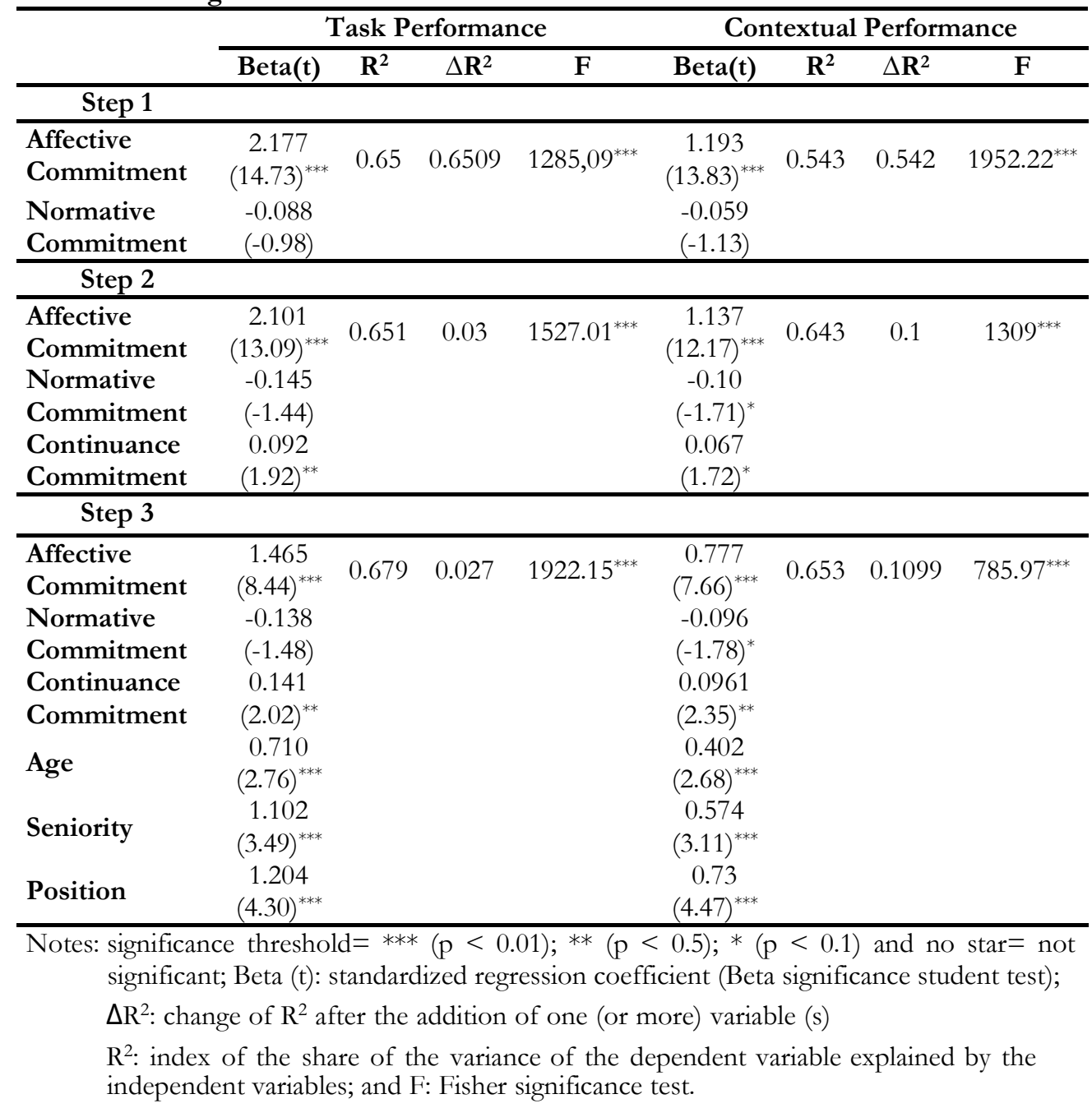


Table 6

Contribution of Age to the Prediction of Tasks and Contextual Performances

\begin{tabular}{|c|c|c|c|c|c|c|c|c|}
\hline & \multicolumn{4}{|c|}{ Task Performance } & \multicolumn{4}{|c|}{ Contextual Performance } \\
\hline & $\operatorname{Beta}(t)$ & $\overline{\mathbf{R}^{2}}$ & $\Delta \mathbf{R}^{2}$ & $\bar{F}$ & Beta $(t)$ & $\overline{\mathbf{R}^{2}}$ & $\Delta \mathbf{R}^{2}$ & $\bar{F}$ \\
\hline \multicolumn{9}{|l|}{ Step 2} \\
\hline $\begin{array}{l}\text { Affective } \\
\text { Commitment } \\
\text { Normative } \\
\text { Commitment } \\
\text { Continuance } \\
\text { Commitment }\end{array}$ & $\begin{array}{c}2.101 \\
(13.09)^{* * *} \\
-0.145 \\
(-1.44) \\
0.092 \\
(1.92)^{* *} \\
\end{array}$ & .651 & .03 & $1527.01^{* * *}$ & $\begin{array}{c}1.137 \\
(12.17)^{* * *} \\
-0.10 \\
(-1.71)^{*} \\
0.067 \\
(1.72)^{*} \\
\end{array}$ & .643 & .1 & $1309^{* * *}$ \\
\hline \multicolumn{9}{|l|}{ Step 3a } \\
\hline $\begin{array}{l}\text { Affective } \\
\text { Commitment } \\
\text { Normative } \\
\text { Commitment }\end{array}$ & $\begin{array}{c}1.993 \\
(12.38)^{* * *} \\
-.175 \\
(-1.76)^{*} \\
\end{array}$ & .6532 & .0022 & $1192.39^{* * *}$ & $\begin{array}{c}1.0758 \\
(11.46)^{* * *} \\
-0.1176 \\
(-2.02)^{* *} \\
\end{array}$ & .6458 & .1019 & $1021.26^{* * *}$ \\
\hline $\begin{array}{l}\text { Continuance } \\
\text { Commitment } \\
\text { Age }\end{array}$ & $\begin{array}{c}.096 \\
(1.29) \\
.873 \\
(3.19)^{* * *}\end{array}$ & & & & $\begin{array}{c}.069 \\
(1.59) \\
0.5002 \\
(3.13)^{* * *}\end{array}$ & & & \\
\hline
\end{tabular}

Notes: significance threshold $=* * *(\mathrm{p}<0.01)$; $^{* *}(\mathrm{p}<0.5) ;{ }^{*}(\mathrm{p}<0.1)$ and no star $=$ not significant.

Table 7

Contribution of Seniority to the Prediction of Tasks Performance and Contextual

\begin{tabular}{|c|c|c|c|c|c|c|c|c|}
\hline & \multicolumn{4}{|c|}{ Task Performance } & \multicolumn{4}{|c|}{ Contextual Performance } \\
\hline & Beta $(\mathrm{t})$ & $\overline{\mathbf{R}^{2}}$ & $\Delta \mathbf{R}^{2}$ & $\bar{F}$ & $\operatorname{Beta}(t)$ & $\overline{\mathbf{R}^{2}}$ & $\Delta \mathbf{R}^{2}$ & $\bar{F}$ \\
\hline Step 2 & & & & & & & & \\
\hline $\begin{array}{l}\text { Affective } \\
\text { Commitment } \\
\text { Normative } \\
\text { Commitment } \\
\text { Continuance } \\
\text { Commitment }\end{array}$ & $\begin{array}{c}2.101 \\
(13.09)^{* * *} \\
-0.145 \\
(-1.44) \\
0.092 \\
(1.92)^{* *}\end{array}$ & .651 & .0003 & $1527.01^{* * *}$ & $\begin{array}{c}1.137 \\
(12.17)^{* * *} \\
-.10 \\
(-1.71)^{*} \\
0.067 \\
(1.72)^{*}\end{array}$ & .643 & .1 & $1309^{* * *}$ \\
\hline Step 3b & & & & & & & & \\
\hline $\begin{array}{l}\text { Affective } \\
\text { Commitment } \\
\text { Normative } \\
\text { Commitment } \\
\text { Continuance } \\
\text { Commitment } \\
\text { Seniority }\end{array}$ & $\begin{array}{c}1.782 \\
(10.32)^{* * *} \\
-0.118 \\
(-1.21) \\
0.099 \\
(1.35) \\
1.376 \\
(4.19)^{* * *}\end{array}$ & .6546 & .0108 & $1230.36^{* * *}$ & $\begin{array}{c}.966 \\
(9.51)^{* * *} \\
-.086 \\
(-1.5) \\
.0705 \\
(1.64)^{*} \\
.7406 \\
(3.85)^{* * *}\end{array}$ & .6497 & .0067 & $1043.43^{* * *}$ \\
\hline
\end{tabular}


Table 8

Contribution of the Position to the Prediction of Tasks and Contextual Performances

\begin{tabular}{|c|c|c|c|c|c|c|c|c|}
\hline & \multicolumn{4}{|c|}{ Task Performance } & \multicolumn{4}{|c|}{ Contextual Performance } \\
\hline & $\operatorname{Beta}(t)$ & $\overline{\mathbf{R}^{2}}$ & $\Delta \mathbf{R}^{2}$ & $\bar{F}$ & $\overline{B e t a}(t)$ & $\mathbf{R}^{2}$ & $\Delta \mathbf{R}^{2}$ & $\bar{F}$ \\
\hline \multicolumn{9}{|l|}{ Step 2} \\
\hline $\begin{array}{l}\text { Affective } \\
\text { Commitment } \\
\text { Normative } \\
\text { Commitment } \\
\text { Continuance } \\
\text { Commitment }\end{array}$ & $\begin{array}{c}2.101 \\
(13.09)^{* * *} \\
-.145 \\
(-1.44) \\
.092 \\
(1.22) \\
\end{array}$ & .651 & .0003 & $1527.01^{* * *}$ & $\begin{array}{c}1.137 \\
(12.17)^{* * *} \\
-.10 \\
(-1.71)^{*} \\
.067 \\
(1.52) \\
\end{array}$ & .643 & .1 & $1309^{* * *}$ \\
\hline \multicolumn{9}{|l|}{ Step 3c } \\
\hline $\begin{array}{l}\text { Affective } \\
\text { Commitment } \\
\text { Normative } \\
\text { Commitment } \\
\text { Continuance } \\
\text { Commitment }\end{array}$ & $\begin{array}{c}1.74 \\
(10.42)^{* * *} \\
-.133 \\
(-1.39) \\
.142 \\
(1.96)^{* *}\end{array}$ & .6563 & .0126 & $1281.64^{* * *}$ & $\begin{array}{c}.923 \\
(9.51)^{* * *} \\
-.093 \\
(-1.67)^{*} \\
.0966 \\
(2.29)^{* *}\end{array}$ & 6497 & .0059 & $1105^{* * *}$ \\
\hline Position & $\begin{array}{c}1.483 \\
(5.25)^{* * *}\end{array}$ & & & & $\begin{array}{c}.881 \\
(5.36)^{* * *}\end{array}$ & & & \\
\hline
\end{tabular}

Notes: significance threshold $=* * *(\mathrm{p}<0.01){ }^{* *}(\mathrm{p}<0.5) ;{ }^{*}(\mathrm{p}<0.1)$ and no star= not significant.

It follows from these analyses that the model (step 1) is very satisfactory, explaining more than $54.2 \%$ of the total variance of contextual performance and more than $65 \%$ of the total variance of task performance (Table 5).

The second step confirms the value of introducing continuance commitment. The explained variance of task performance increased by $3 \%$ to reach $65.1 \%(\Delta \mathrm{F}=241.92, \mathrm{p}$ $<0.01)$ and that of contextual performance increased by $10 \%$ to attain $64.3 \%(\Delta \mathrm{F}=$ 643.22, $\mathrm{p}<0.01$ ), when the construct "continuance commitment" was introduced.

The contribution of the measure "normative commitment" (marginal in step 1) is no longer significant at this stage. However, "affective commitment" has a stronger influence on job performance than "continuance commitment".

The hypothesis that organizational commitment positively and significantly affects job performance is validated only partially.

Step 3 introduces "age", "seniority" and "position" to explore the possibility that other factors of organizational commitment contribute to the improvement of job performance.

Although these three new variables have a significant effect on task performance $(\Delta \mathrm{F}=395.14, \mathrm{p}<0.01)$ and contextuel performance $(\Delta \mathrm{F}=523.03, \mathrm{p}<0.01)$. The percentage of the additional variance explained is moderate for contextual performance and also for task performance $\left(\Delta \mathrm{R}^{2}=10.9 \%\right)$ and $\left(\Delta \mathrm{R}^{2}=2.7 \%\right)$, respectively.

The "age" variable contributes to an improvement of $\mathrm{R}^{2}$ of the order of $0.22 \%$ (marginal effect) (Table 6), the "seniority" brings an increase of $\mathrm{R}^{2}$ by $1.08 \%$ (marginal effect) (Table 7). Nonetheless, from a practical point of view, the introduction of the variable "position" is of great use, with an improvement of $1.26 \%$ (Table 8).

Moreover, the extension of the model to the variables "age", "seniority" and "position" highlights the significant and desirable (although marginal) contributions of these variables to the prediction of job performance under the double dimensions (task and contextual). 
The relationship between organizational commitment and job performance is partially validated. Affective commitment has a positive and significant impact on job performance as the accounting professionals are affectively attached to the firm. This result is in line with that of Metin and Asli (2018). However, continuance commitment has a positive and significant impact on performance due to the lack of alternatives for professionals. This result is in agreement with that of Rafiei et al. (2014). However, normative commitment has a negative and no significant effect on performance as there is are no loyal behaviors towards the firm for accounting professionals in the Tunisian context. This result is consistent with Meyer et al. (1993).

\section{CONCLUSION}

We aimed to study the impact of organizational commitment (OC) on job performance of accounting professionals working in Tunisian accounting firms.

Following the literature review, we posed three main sub-hypotheses in the aim of our work. They deal with the impact of affective, normative, and continuance commitment on job performance of accounting professionals.

To validate our hypotheses on the impact of organizational commitment on job performance, we chose to present this influence by hierarchical regression, which seems more pertinent in explaining this relationship. However, to underline the significance of the variables age, seniority, and position in the relationship between commitment and performance, our results of the estimates show the paramount importance of these three variables. However, seniority is the most important one.

Our results show that the relationship between organizational commitment and job performance of accounting professionals is partially validated. Indeed, both affective and continuance dimensions have a positive and significant impact on performance. However, normative commitment has a negative and no significant effect on performance.

\section{REFERENCES}

Al Zeifiti, S. M. B., \& Mohamad, N. A. (2017). The influence of organizational commitment on Omani public employees' work performance. International Review of Management \& Marketing, 7(2), 151-160.

Bagozzi, R. P., Yi, Y., \& Phillips, L. W. (1991). Assessing construct validity in organizational research. Administrative Science Quarterly, 36(3), 421-448.

Berberoglu, A., \& Secim, H. (2015). Organizational commitment and perceived organizational performance among health care professionals: Empirical evidence from a private hospital in Northern Cyprus. Journal of Economics \& Behavioral Studies, 7(1), 64-71.

Choo, F. (1986, January). Job stress, job performance and auditor personality characteristics. Auditing a Journal of Practice \& Theory, 5(2), 17-34.

Dixit, V., \& Bhati, M. (2012). A Study about employee commitment and its impact on sustained productivity in Indian auto-component industry. European Journal of Business \& Social Sciences, 1(6), 34-51.

Evrard, Y., Pras, B., Roux, E., Choffray, J.-M., Dussaix, A., \& Claessens, M. (1997). Market - etudes et recherches en marketing: Fondements, methodes ( $2^{\text {nd }}$ ed.). Nathan, Paris.

Fisher, R .T. (2001). Role stress, the type a behavior pattern, and external auditor job satisfaction and performance. Behavioral Research in Accounting, 13(1), 143-170. 
Folorunso, O. O., Adewale, A. J., \& Abodunde, S. M. (2014). Exploring the effect of organizational commitment dimensions on employees performance: An empirical evidence from academic staff of oyo state owned tertiary institutions, Nigeria. International Journal of Academic Research in Business \& Social Sciences, 4(8), 275-286.

Ghorbanpour, Z., Dehnavi, H. D., \& Heyrani, F. (2014, February). Investigating the effect of organization commitment on performance of auditors in the community of certified accountants. Interdisciplinary Journal of Contemporary Research in Business, 5(10), 199-209.

Irefin, P., \& Mechanic, M. A. (2014, March). Effect of employee commitment on organizational performance in coca cola Nigeria limited Maiduguri, Borno state. IOSR Journal of Humanities \& Social Science (IOSR-JHSS), 19(3), 33-41.

Kamis, R. A., Noermijati, \& Susilowati, C. (2013). The influence of organizational commitment and individual competence on teacher performance: In the learning organization perspective. International Journal of Business \& Behavioral Sciences, 3(8), 19-35.

Krishnanathan, P., \& Mangaleswaran, T. (2018). Organizational commitment and employee performance with special reference to administrative officers at the University of Jaffna, Sri Lanka. Research Journal of Education, 4(6), 82-86.

Liden, R. C., Wayne, S. J., \& Sparrowe, R. T. (2000, July). An examination of the mediating role of psychological empowerment on the relations between the job, interpersonal relationships, and work outcomes. Journal of Applied Psychology, 85(3), 407-416.

Mansour, N., Gara, E., \& Gaha, C. (2013). Getting inside the black box: HR practices and firm performance within the Tunisian financial services industry. Personnel Review, 43(4), 490-514

Memari, N., Mahdieh, O., \& Marnani, A. B. (2013, September). The impact of organizational commitment on employees job performance: A study of Meli bank. Interdisciplinary Journal of Contemporary Research in Business, 5(5), 164-171.

Metin, K., \& Asli, K. (2018, March). The relationship between organizational commitment and work performance: A case of industrial enterprises. Journal of Economic \& Social Development, 5(1), 46-50.

Meyer, J. P., \& Allen, N. J. (1991). A Three-component conceptualization of organizational commitment. Human Resource Management Review, 1(1), 61-89.

Meyer, J. P., \& Allen, N. J. (1997). Commitment in the workplace: Theory, research, and application. Thousand Oaks, California: Sage Publications, Inc.

Meyer, J. P., Allen, N. J., \& Smith, C. A. (1993). Commitment to organizations and occupations: Extension and test of a three-component conceptualization. Journal of Applied Psychology, 78(4), 538-551.

Rafiei, M., Amini, M. T., \& Foroozandeh, N. (2014). Studying the impact of the organizational commitment on the job performance. Management Science Letters, 4(8), 1841-1848.

Raza, M. Y., Akhtar, M. W., Husnain, M., \& Akhtar, M. S. (2015). The impact of intrinsic motivation on employee's job satisfaction. Management \& Organizational Studies, 2(3), 80-88.

Schawartz, F. (1978, March). Estimating the dimension of a model. The Annals of Statistic, 6(2), 461-64. 
Shaw, J. D., Delery, J. E., \& Abdulla, M. H. A. (2003, February). Organizational commitment and performance among guest workers and citizens of an Arab country. Journal of Business Research, 56(12), 1021- 1030.

Suharto, Suyanto, \& Hendri, N. (2019). The Impact of organizational commitment on job performance. International Journal of Economics \& Business Administration (IJEBA), 7(2), 189-206.

Wayne, S. J., Shore, L. M., Bommer, W. H., \& Tetrick, L. E. (2002, July). The role of fair treatment and rewards in perceptions of organizational support and leadermember exchange. Journal of Applied Psychology, 87(3), 590-598. 